\title{
Why U.S. Health Care Reform Is So Difficult
}

\author{
by W. Andrew Achenbaum
}

\section{$\mathrm{H}$}

ealth care reform now heads the U.S. domestic agenda, but this generation of policymakers may be less successful than its predecessors in effecting major changes. The president wants universal coverage and a wider array of services. Key members of both parties, such as Senators Dole and Moynihan, resist anything so grandiose. "Yes, there are problems," declared the Republican congressional leadership. "But there's not an emergency that requires a complete overhaul of the medical system." The current debate pits visions of justice and fairness against fears that reforms may prove more costly and cumbersome than maintaining the status quo.

Promoting "the general welfare" is tough in a country where progress is measured incrementally. Advances occur in fits and turns, "watersheds" alternate with retrenchments. "The two parties which divide the state, the party of Conservatism and that of Innovation are very old. . . Reform is affirmative, conservatism negative," Ralph Waldo Emerson observed in 1841. "The Conservative assumes sickness as a necessity, and his social frame is a hospital. ... Reform converses with possibilities, perchance with impossibilities." In this dialectic, "Innovation is the salient energy; Conservatism the pause on the last movement."

W. Andrew Achenbaum is deputy director and professor of history at the Institute of Geromtology of the University of Michigan, Ann Arbor.

W. Andrew Achenbaum, "Why U.S. Health Care Reform Is So Difficult," Hastings Center Report 24, no. 5 (1994): 23-25.
Reformism's ebb and flow was not a uniquely American characteristic; liberals fought conservatives everywhere. But Emerson claimed that U.S. politics had generational underpinnings. Fresh ideas came from new blood, from reformers surmounting old ways and vested interests- - "rest, conservatism, appropriation, inertia; not newness, not the way onward." Partisan battles here were ideological, waged by forward-looking members of a rising generation against the elderly guardians of the established order.

Sometimes, of course, members of the same cohort represented the interests of innovation and conservatism. Debating among themselves a generation earlier, for instance, the Founding Fathers wrestled with how to balance the creative policy recommendations advanced by leaders coming into their own and the prudent voices of those who valued the steady hand of tradition. From the late 1780s until his death, Thomas Jefferson stressed that each generation had "the right to direct what is the concern of themselves alone, and to declare the law of that direction... to make the Constitution what they think will be best for themselves." Jefferson wrote in a letter in 1816 that the Constitution should make provisions for its own revision every nineteen or twenty years, "so that it may be handed on, with periodical repairs, from generation to generation, to the end of time."

James Madison, in contrast, stressed the importance of continuity in transferring rights and responsibilities from generation to generation. "There seems then to be a foundation in the nature of things, in the relation which one generation bears to another, for the descent of obligation from one to another," Madison wrote to his neighbor at Monticello in 1790. "Equity requires it .... [and] good is promoted by it." ${ }^{5}$ Given humans' innate capacity for selfishness and opportunism, Madison relied on "traditional" conventionsinstilling a sense of duty in the citizenry, honoring contracts that were legitimately made by representative governments-to dilute the naiveté of political neophytes and to mitigate the establishment's abuse of power.

At still other critical moments in our history, U.S. politicians have muted inter- and intragenerational disagreements over policy differences. Lawmakers in the depths of the Great Depression emphasized that "relief, reform, and reconstruction" actually offered the best way to preserve the core of the American experiment. Thus, in bringing together experts to draft social security legislation, Franklin Delano Roosevelt declared:

Our task of reconstruction does not require the creation of new and strange values. It is rather the finding of the way once more to known, but to some degree forgotten, ideals and values. If the means and details are in some instances new, the objectives are as permanent as human nature. ${ }^{6}$

The. landmark Social Security Act of 1935 passed because it broadly appealed to the nation's "vital center." Provisions for the indigent, the blind, and the elderly, as well as the funds earmarked for research and training, were all designed to give citizens new entitlements. The measure buttressed the traditional support that children owed their parents while enabling future generations to save for their retirement years.

FDR's blue-ribbon panel realized that illness was one of the major causes of economic insecurity. By their estimates, one-third to one-half of all dependency in the U.S. in "normal times" stemmed from the economic consequences of illness. Massive unemployment and cutbacks in services during the Depression, moreover, reduced the access of lowerincome workers and their families to physicians and health care institu- 
tions. Mindful both of the progressives' success in securing legislation to compensate against income losses due to industrial accidents and their failure to enact compulsory insurance against sickness, New Deal reformers set the stage for innovation:

Insurance against the costs of sickness is neither new nor novel. In the United States we have had a long experience with sickness insurance both on a nonprofit and commercial basis. Both forms have been inadequate with respect to the protection they furnish, and the latter-commercial insurance-has in addition been too expensive for people of small means. Voluntary insurance holds no promise of being much more effective in the near future than it has been in the past. ${ }^{7}$

After deciding not to include health care insurance in its omnibus legislation, the Committee on Economic Security, as a "first and most inexpensive step in furnishing economic security against illness," requested funds to prevent sickness. Grants-in-aid were to provide public health services in areas where none existed. (In 1933, only a sixth of the nation's counties had full-time health supervision.) Funds were allocated to train more personnel. (Only 21 percent of the existing local departments were providing "a satisfactory minimum" standard in dealing with health-related problems.)

Noting that "nearly every large and industrial country of the world except the United States has applied the principle of insurance to the economic risks of illness," tee charted a pragmatic agenda for their successors. They envisioned a health system that pooled risks. Policymakers set a 4.5 percent cap on a family's contribution for medical coverage. The medical profession would control personnel and services, and negotiate fees. Services would be administered on a statewide basis, with the federal government establishing national standards and providing necessary subsidies. Philosophically and structurally, the committee's blueprint for health care reform meshed with the logic and form of its Social Security Act.
As was the case with New Deal income-maintenance programs, agespecific differences in people's health status were acknowledge but not accentuated: "With the changing age composition of our population the task of health conservation must be broadened to include adults as well as children." ${ }^{9}$ Reformers ultimately hoped to reduce every cohort's risk by providing universal coverage over the life course. Faced with limited resources and considerable opposition, they opted for an incremental approach, addressing needs that could be remedied with the least political cost.

New federal investments, incentives, and rulings restructured the nation's health care institutions after World War II. The Veterans Administration, which operated the largest hospital system in the U.S., became the major training site for physicians and nurses. The National Institutes of Health grew into the world's largest center for biomedical research. The Hill-Burton Act (1946) provided billions for hospital construction, which increased the number of beds available in low-income states and middle America. Changes in the tax code during the 1950s exempted employers' contributions to health benefit plans. By 1954, 12 million union members and their 17 million dependents enjoyed Blue Cross/Blue Shield coverage. Some workers took advantage of prepaid group practice options like the Kaiser plan.

As conservatives and innovators in each Congress haggled over details, additional health care benefits were gradually extended to certain classes of Social Security recipients. The 1950 amendments provided meanstested payments to the disabled. Broader disability provisions were added during the Eisenhower years for those too young to retire but incapable of staying in the labor force. The Kerr-Mills Act (1960) allocated funds for people not on public relief who could not pay for necessary medical treatments. Each legislative victory heightened public interest in medical insurance, which in turn presaged another wave of health care innovation in Washington.

"We can-we must-strive now to ensure the availability and accessi- bility to the best health care for all Americans regardless of age or geography or economic status," proclaimed Lyndon Baines Johnson, setting a major goal for his Great Society. ${ }^{11}$ A new generation of reformers focused on the needs of the elderly, who constituted the poorest and sickest segment of society. In 1965, the president signed Medicare into law. The measure extended hospital insurance to Social Security beneficiaries, and featured a voluntary plan to cover physicians' bills. Just as old-age assistance in 1935 had been considered a necessary complement to old-age insurance, so too Medicaid (which provided medical services for welfare recipients of all ages) was enacted in the shadow of Medicare. Incrementalism continued. Social Security amendments in 1972 permitted reimbursements for kidney dialysis and transplants, chiropractic and podiatry services under Medicare, and liberalized Medicaid payments for nursing home care.

These 1972 amendments, however, also signaled Congress's first efforts to limit health care outlays. Medicare authorized certain services on a capitation basis and established review boards to monitor quality and utilization of resources. Medicaid permitted states to impose copayment requirements on recipients. ${ }^{12}$ Ford's and Carter's calls for greater stringency floundered. Ronald Reagan was the first president to succeed in framing the health care debate in economic terms. Congress, however, was loath to consider measures that might hurt the poor and the elderly. The Catastrophic Coverage Act (1988) provided new benefits in a seemingly budget-neutral fashion. But Congress repealed the measure two years later when faced with considerable backlash from the very constituency it meant to help. That relatively affluent senior citizens were unwilling to pay for catastrophic coverage exposed intragenerational cleavages in the electorate.

The fight over catastrophic insurance was symptomatic of larger fiscal woes, structural dysfunction, and stereotypic reasoning. Increases in life expectancy were a source of national pride, but population aging was scary: it raised the specter of ad- 